\title{
EXPANSION OF COMMUNICATION MEDIA TECHNOLOGY AND ITS IMPACT IN TRIBAL VILLAGES: A CASE STUDY OF GARGOTWADI VILLAGE IN NANDED DISTRICT (M.S)
}

\author{
Dr. V. Rajeshwar, \\ Director, \\ All India Radio, Nizamabad (T.S) \\ air_nzb@yahoo.com
}

\begin{abstract}
There are many types of Tribes residing in India and have been spread throughout the length and breadth of the country. They constitute nearly 7.5 per cent of the total population of the country. Tribal villages are isolated without much connectivity and there is information poverty also when compared with other villages, towns and cities. The tribes are largely indulged in face-to-face communication and live in a clearly bounded place. They live with relatively strong kinship relations, without much contact from the outside world. Due to their isolation most of the goods and services are of reciprocal exchange with in their limited spheres of life.

But, due to developmental policies of the government the roads, transportations facilities have been improved in tribal areas. The communication media technologies such as radio, television and mobile phones etc are expanding or penetrating into the isolated tribal villages to establish connectivity and integrating them into the rest of the world. The tribal people are now using various mass media and exposed with non-local information, education and entertainments, which is manifesting into significant social changes. The reciprocal exchanges of goods and services among tribes have also been collapsing and in its place marketing relations are establishing with the use of currency. The tribal socio-economic conditions are also being improved due to tribal sub-plans, reservations in education and employment.
\end{abstract}

This paper presents the finding of the study on the use of communication media technology in a typical tribal and its impact in their day to day life.

Key words: DTHTV, Impact, Mobile Phones, Radio, Tribes.

Introduction: From the beginning human beings gathered information through communication before arriving at a decision for survival and growth. Information and communication becomes inevitable for all human activities. Uma Joshi (2001) explained that, Information and communication has the power to change the society socio-economically also. The $21^{\text {st }}$ century is the age of information as it became big industry. Many varieties of communication systems are serving the people for fulfillment of various needs. Ahuja and Batra (1978), explained that, the communication media technology is changing the society with rapid speed with the usage of one way modern mass media such as Print, Radio, films and Television. Later, Satellite communication particularly DTH TV and Internet made the world global village. The internet and its associated new media technologies have the capabilities for two way interactivity such as Podcasts, Blogs, RSS Feeds, Hyper texts, Wikis and Social networking.

Traditionally tribes are indulged in face to face oral interaction and with folk media for information sharing and entertainment. Now, the situation has changed and the communication media technologies are penetrating into isolated 
tribal villages. The tribes sharing of information and entertainment are also gone into a paradigm shift due to penetration of media. Abdul Miah and Abdul Halim (1994), explained that, Information flow is required from information rich to information poor places to make human beings aware of latest knowledge happening around the world particularly to improve agriculture. This is so in tribal areas with the use of interpersonal communication alone one cannot disseminate scientific information of agriculture without the help of modern media. The Radio and DTH TV are broadcast media delivers the messages simultaneously to millions of people by wiping out the geographical and social barriers of communication. Only one needs to have Radio and Television sets to receive the message. The communication environments in the village are also changed due to liberalization and deregulation of media and penetration of Mobile Phones, Radio and DTH TV.

Objectives of the study: A study was under taken to measure the impact of communication media technologies (Mobile phones, Radio and DTH TV) in remote tribal village (Gargotwadi) with the following objectives:

1) To examine the ownership of communication media technologies such as Radio, DTH TV and Mobile phones for information sharing, entertainment etc.

2) To assess the active participation of tribes in mobile phone usage, listening to radio broadcasts and watching to DTH TV broadcasts.

3) To examine the impact and benefits the tribes are deriving from the media in their life.
Materials and Methods: To find the answers to the above objectives, village survey is conducted with a structured questionnaire. The questionnaire was prepared incorporating independent variables such as name, age of the respondents, occupation, ownership of Mobile Phones, Radio and DTH TV sets etc. The dependent variables are pertaining to the purpose of using the above communication devices, such as information, entertainment, education, interactivity and frequency of the media used etc and the benefit they derived from them.

Location of the Gargotwadi Village: Maharashtra State highway No. 230 passes through Bhokar and Mudkhed Towns of Nanded District. Pandurna village is situated on this highway between Mudkhed and Bhokar. The Gargotwadi tribal village is located $1.5 \mathrm{Km}$ away from Pandurna. It is located in forest areas of the District on a small hilltop and can be seen from this State High way. Two years back bituminous road was laid between Pandurna and Bosi villages which pass through Gargotwadi. The tribal village is falls under Bhokar Tahasil in Nanded District. It is surrounded by hill hops and dry land agriculture fields.

Let me explain the findings and analysis of social composition and communication media technology (Mobile Phones, Radio and DTH TV) and its impact in Gargotwadi village.

Social Composition of Gargotwadi Village: Banjaras and Aundh are the only two tribes living in Gargotwadi. The village consists of 130 households. Of the total village survey, 75 (58 per cent) families belong to Aundh which is a scheduled tribe 
and about, 55 (42 per cent) families belong to Banjaras (Lambadas) which is a Vimukta Jati (VJ DT) De notified tribe.

Table 1. social composition of Gargotwadi

\begin{tabular}{|c|c|c|c|c|c|c|}
\hline \multirow[t]{2}{*}{$\begin{array}{l}\text { Name of the } \\
\text { Tribe }\end{array}$} & \multicolumn{2}{|c|}{ Age of the householder } & \multicolumn{2}{|c|}{$\begin{array}{l}\text { Sex of the house } \\
\text { holder }\end{array}$} & \multicolumn{2}{|c|}{$\begin{array}{l}\text { Primary occupation } \\
\text { of householder }\end{array}$} \\
\hline & $\begin{array}{l}\text { More than } 45 \\
\text { Years }\end{array}$ & $\begin{array}{l}\text { Less than } 45 \\
\text { Years }\end{array}$ & $\mathbf{M}$ & $\mathbf{F}$ & Agriculture & Others \\
\hline Banjara -55 & $21(38)$ & $34(62)$ & $52(95)$ & $3(5)$ & $52(95)$ & $3(5)$ \\
\hline Aundh- 75 & $28(37)$ & $47(63)$ & $68(91)$ & $7(9)$ & 55(73) & 20(27) \\
\hline Total 130 & $49(48)$ & $81(62)$ & $120(92)$ & $10(8)$ & $107(82)$ & $23(18)$ \\
\hline
\end{tabular}

In Gargotwadi, 62 per cent of the families are headed by young persons of the age below 45 years. Nearly, 92 per cent of the households are headed by males and 8 per cent by females. The female head of the families reported that their husband died at young age due to ill health and some committed suicide due to economic pressures. Of the total village survey, the primary occupation of 82 per cent families is agriculture and 18 per cent are in other occupations which include laborers, government and private sector employees. Large numbers of families nearly 30 per cent are migratory laborers in the village. It is informed that during migration, they are involved in Mirchi compound, Cotton mills and Agriculture markets as Hamalis at Bhainsa, Nirmal, Adilabad and Nizamabad towns in Telangana for survival.

Demographically in the village, Audth is the dominant tribe and their manners, religion and language are resembles like poor agriculture Maratha Kunbis. Their social organization and culture also resemble like caste system. They speak Marathi and don't have their own language, culture etc, and are similar to the general public of the District. They are engaged in agriculture and buffalos rearing. But, the Banjaras appears fairer and district and look like tribe with distinct language, dress, costumes, cultural practices, songs, dances and mythological stories. They speak their Banjaras language which has no script and carry forward their language with oral tradition only. In spite of being distinct it is categorized in Vimukta Jati Denotified Tribe (VJDT). They are engaged in cultivation, cows and goat rearing. Both the tribes in Gargotwadi are doing dry land agriculture due to scarcity of water and dependent on rains. They also started using modern agricultural inputs and machines. Living in the same village the Aundh are also learned to speak Banjaras language. Similarly, the Banjaras are also speaking Marathi language. This way the tribes are acquiring multi-language capability for communication and information sharing.

Expansion of Mobile phones, Radio and DTH TV Services into the tribal village: The Mobile phones are public utility services which are being commercialized due to liberalization policies and this led to healthy competition among public and private mobile operators. The prices of 
mobile phone services have come down and the utility is rising and penetrated into tribal village. The Nanded District has two FM Radio stations, the first one belong to All India Radio (FM) ( AIR) operating at 101.1 $\mathrm{MHz}$ frequency with $6 \mathrm{KW}$ power and other is of M/s Radio City operating at 91.1 $\mathrm{MHz}$ frequency with $5 \mathrm{KW}$ power. The AIR station has studio facility for local programme production and broadcasting from $6.00 \mathrm{am}$ in the morning to $11.00 \mathrm{pm}$ in the evening. The Radio City is a relay station and broadcasting only in the evening from $5.00 \mathrm{pm}$ to $11.00 \mathrm{pm}$. Both the stations are fulfilling the needs of rural and urban audiences. The AIR station is encourages the local Artists and Experts. Radio is the cheapest, portable media operates with batteries and acted as catalyst for social change.

In the Nanded District, six low power TV (LPTV) terrestrial transmitters for DD National channel are installed at Nanded, Digloor, Kinwat, Bhokar, Dharmabad and Umarkhed. These transmitters are relaying the National and State TV programs and Gargotwadi village is not receiving signals from these transmitters. However, many National and Foreign TV channels on DTH TV are received; some of them are namely Alpha Marathi, Lokmat TV, ETV Marathi, Channel V, Star TV, Zee TV, NDTV, MTV etc. The International channels available on DTH include ESPN, MTV, BBC world, CNN, HBO, CN, Discovery, National Geography, Star movies, Star TV, Sony etc., The National channels broadcast in Hindi and regional languages such as in Marathi and International channels broadcast in English and other foreign languages.

Therefore, Gatgotwadi village is receiving Mobile Phone, All India Radio, Radio city and DTH TV signals.

Mobile Phones, Telephone and Internet Services in Gargotwadi:

Table 2. Ownership of Mobile phones, Telephones, Internet

\begin{tabular}{|l|l|l|l|}
\hline \multirow{2}{*}{$\begin{array}{l}\text { Name of the } \\
\text { Tribe }\end{array}$} & \multicolumn{3}{|l|}{$\begin{array}{l}\text { Telephone, Mobile Phone and Internet Services of } \\
\text { householders }\end{array}$} \\
\cline { 2 - 4 } & Telephone & Mobile Phone & Internet \\
\hline Banjara -55 & $\ldots$ & $\mathbf{5 0}(90.9)$ & \\
\hline Aundh- 75 & $\ldots$ & $\mathbf{5 5}(\mathbf{7 3 . 3})$ & $\ldots$ \\
\hline Total -130 & $\ldots$ & $\mathbf{1 0 5}(\mathbf{8 0 . 7})$ & $\ldots$ \\
\hline
\end{tabular}

Note: Parenthesis represents percentage

Significantly 90.9 per cent of Banjara and 73.3 per cent of Aundh own Mobile Phones in the village. The land line telephone is provided under Bharat Nirman Yojna by M/s BSNL with coin box facility and at the time of survey it was not working. All the villagers are using Mobile Phone particularly from Private operators such as, Air Tel, Idea and Vodafone, because of their good marketing in tribal areas, with user friendly options. In the village, College going students, employees and teachers are aware of Computers and Internet, but no family has taken Internet connection. It is 
informed that using Mobile Phones interaction becomes instant and less costly.

To summarize the impact, the owning the Mobile Phones are not dependent on socio- economic conditions and land holdings of the farmers. The landless, marginal farmers also equally own Mobile Phones for their everyday utility. The Mobile Phones have revolutionized the tribes in interpersonal communication. Mobile Phones have become primary sources of sharing feelings, enrichment of human relations, distant relatives tonal voices are heard in the village and it made them feel like as if in face to face close interaction. Mobile Phones dissolved the boundaries of space and time to contact with relatives and agencies at any place and at any time of the day. With the use of mobile phones tribes learned new etiquettes while conversation, for example they often start mobile conversation with a greeting saying "hello".

Mobile phones have camera facilities to take photographs and store their family photos. Some mobile phones have the facilities to store audio-video Programmes for the listening and watching purposes during leisure time. The melodious songs are listened by youth with mobile phones. The ringing sounds of mobile phones are most often listened in the village. Although, it is difficult to change the habits of old aged, but they have learned the operation of mobile phones and using them. Mobile phone is leading media device with multifunctional facilities used for interpersonal communication and to receive radio broadcast, text and video. The Migratory labors from Gargatwadi are using the Mobile Phones to contact their family members in the village in regular manner. Tribes are also using it to contact the Veterinary and R.M.P doctors in case of emergencies. The short message service (SMS) is very much used by educated tribes in sharing of greeting on birth days, on festivals.

Ownership of Radio, Television and DTH Services in Gargotwadi :

Table 3. Ownership of Radio, Mobile phones with FM radio, DTH TV in Gargotwadi

\begin{tabular}{|l|l|l|l|}
\hline \multirow{2}{*}{$\begin{array}{l}\text { Name of the } \\
\text { Tribe }\end{array}$} & \multicolumn{3}{|l|}{ Radio, Television and DTH householders } \\
\cline { 2 - 4 } & Radio & Mobile Phone with FM Radio & DTH Television \\
\hline Banjara- 55 & $11(20)$ & $26(47.2)$ & $7(12.7)$ \\
\hline Aundh - 75 & $17(23)$ & $42(56)$ & $9(12)$ \\
\hline Total - 130 & $28(22)$ & $88(67.7)$ & $16(12.3)$ \\
\hline
\end{tabular}

Note: Parenthesis represents percentage

In Gargotwadi, around 23 per cent Aundh and 20 per cent Banjara own Radio sets. Significantly, 47.2 per cent of Banjara and 56 per cent of Aundh owns Mobile
Phones with FM Radio facilities. From this village not even a single person participated in the programmes produced in AIR Nanded and they are the passive listeners. Nearly, 
12.7 per cent of the Banjara and 12 per cent of Aundh families own DTH TV sets. The only 2 Aundh families are using DTH of Doordarshan free to air broadcast and rest are paid connections from Tata Sky and Videocon.

The tribes are engaging with media extensively due to abundant choices to tune to their programmes of interest. The poverty is no more an issue to own the DTHTV, Radio and mobile phones and all the villagers would like to own them as it is a source of information and entertainment. Tribes are getting entertained through listening to FM radio broadcasts of AIR Nanded with mobile phone ear phones as well as with radio sets. In spite of being very cheap media, the purchasing of Radio sets slowed down due to competition from DTH TV and Mobile Phones which are available at considerable low prices in the market.

Listening patterns of Gargotwadi audience to various Radio Bradcasts:

Table 4. Frequency of listening to various types of Radio broadcasts in Gargatwadi

\begin{tabular}{|l|l|l|l|l|l|l|}
\hline \multirow{2}{*}{$\begin{array}{l}\text { Name of the } \\
\text { broadcast }\end{array}$} & \multicolumn{6}{|l|}{ Listening to various types of Radio Broadcasting } \\
\cline { 2 - 7 } & \multicolumn{2}{|l|}{ Aunjara -55} & Aundh- 75 \\
\cline { 2 - 7 } & Regular & Occasional & Rare & Regular & Occasional & Rare \\
\hline Entertainment & $6(10.9)$ & $4(7.2)$ & $1(1.8)$ & $12(16)$ & $3(4)$ & $2(2.6)$ \\
\hline Information & $4(7.2)$ & $5(9)$ & $2(3.6)$ & $7(9.3)$ & $6(8)$ & $4(5.3)$ \\
\hline Education & $2(3.6)$ & $4(7.2)$ & $5(9)$ & $2(2.6)$ & $5(6.6)$ & $10(13.3)$ \\
\hline
\end{tabular}

Note: Parenthesis represents percentage

In Gargoatwadi, around 16 per cent of Aundh and 10.9 percent of Banjaras are regularly listening to Entertainment broadcast of Radio. The Vividh Bharati and film songs broadcast are most listened in the village. Similarly, around 9.3 Aundh and 7.2 per cent Banjara listened to informational broadcast. And nearly, 2,6 per cent of Aundh and 3.6 per cent of Banajras are regularly listening to Educational broadcast.

To summarize the impact, Radio broadcasting has the ability to connect performing artists and experts, National personalities with tribes. The AIR Nanded is producing very popular programme for broadcast daily in the morning namely 'Nanded Darpan' for providing vital information happening in District every day and is preferred in listening compared to
Regional, State and National News relayed from AIR Nanded. It shows that villagers are more interest in knowing local news events compared to events taking place elsewhere. The private FM "Radio city" is relaying mostly entertainment broadcast produced based on Filmy music, chatting on Youth affairs, Relationships, arts etc.

From the survey it became clear that, Radio listening is mostly used for awareness and entertainment purpose rather than economic generating activity. The Radio offers freedom to combine work while listening to it. Because of this quality of the routine life in the remote Gargotwadi starts with listening to Radio programs in the morning. The cultivators can do cultivation, house wife can cook food and the student can do mathematics to enhance performance 
and to reduce fatigue while listening to Radio. National immunization campaigns and advertisements is carried out to eradicate Pulse Polio Virus, AIDS awareness, Two child norms and Family planning and Literacy mission, Girl Child Promotion, Pregnant woman health,
Children Education etc are some of the important broadcast from AIR Nanded.

Viewing patterns of audiences in Gargotwadi to various types of TV broadcasts:

Table 5. Frequency of listening to various types of TV broadcasts:

\begin{tabular}{|c|c|c|c|c|c|c|}
\hline \multirow{3}{*}{$\begin{array}{l}\text { Name of the } \\
\text { Broadcast }\end{array}$} & \multicolumn{6}{|c|}{ Watching to Television Broadcasting } \\
\hline & \multicolumn{3}{|c|}{ Banjara -55 } & \multicolumn{3}{|c|}{ Aundh- 75} \\
\hline & Regular & Occasional & Rare & Regular & Occasional & Rare \\
\hline Entertainment & $12(22)$ & $\ldots$ & $\ldots$ & $9(12)$ & $\ldots$ & $\ldots$ \\
\hline Information & $6(11)$ & $4(7.3)$ & $2(3.6)$ & $6(8)$ & $3(4)$ & $\ldots$ \\
\hline Education & $2(1.7)$ & $3(5.5)$ & $7(12.7)$ & $2(2.7)$ & $3(4)$ & $4(5.3)$ \\
\hline
\end{tabular}

Note: Parenthesis represents percentage

In Gargotwadi, around 12 per cent of Aundh and 22 per cent of Banjaras watch entertainment broadcasts regularly. Nearly, 8 per cent of Aundh and 11 per cent of Banjaras watch the informational broadcasts regularly on DTH TV. Very less, around 2.7 per cent of Aundh and 1.7 per cent of Banjaras watched the Educational broadcast regularly on TV.

The tribes are watching two to three hours at a time if the programme broadcast is a Film or an entertaining episode. The Banjaras watch more TV compared to Aundh tribes. They are watching Soaps, Film songs, Humor etc., continuously till the broadcast ends. The Drama and Soaps are more watched by the women members. Educational broadcast are least watched in Gargotwadi. In particular, TV models the standards of behavior by portraying the characters in the serials and films which have impacted on life styles and aspirations of tribes. As mentioned, the TV Programmes are not produced in Nanded District for broadcasts. The broadcast content, artists and presenters are also not belonging to Nanded. All the broadcast are related to State, National and International issues. However, tribes are flocked more often to the TV. The tribes goes on changing the channels for want of entertainment Programmes with remote. The movies and entertainment broadcasts are generally watched by men, women and children in equal manner. In the tribal village religious channels are being watched regularly on TV due to faith on religious matters. The TV is becoming a moral teacher to the children by broadcast of mythological films in the forms of Cartoons. Even the News and current affairs also take the shape of either entertainment or propaganda formats and called them infotainments.

The tribes are exposed to foreign countries, people, cultures and their living conditions. In Gargotwadi, tribal cultural flavors are fading out and in its place popular Hinduism, Western culture and 
beliefs are started replacing. The resisting tendencies of tribes to foreign cultures and Information are declining and welcoming them for enjoying, socio-economic progress and to integrate in the global world. The tribal people have become aware of multinational products and services through the advertisements as TV is the main media for the Indian industry. Television is a lively media. The TV News channels are showing lively on Wars, Conflicts, Calamities and other Crises taking place anywhere in the world. The real devastation of Cyclone, Tsunami, Floods, Earth quakes are brought to the villages by DTH TV. The TV media show live coverage in the name of "Breaking news" or "Hot news" within a fraction of time world wide which impact immediately and go into the memories of tribes. With the use of DTH TV and Radio technology the culture and life style are charging and becoming primary agents of social change process. Media is impacting on socializations and become the cultural versions of the tribal.

\section{Conclusions:}

Mobile phones, Radio and DTH TV have penetrated into the tribal village and tribes are deriving benefits. Social changes are taking place with the exposure to new information, entertainment and learning. The tribal people consciousness about information, entertainment and information cognition is rising. The tribes are becoming conscious about other people, their living styles, environment and larger society around the world. However, interactive new media involving internet and its associated technologies such as Podcasts, Blogs and Social Networking technologies have not yet penetrated into the tribal village. The studied village already entered into information age and become the part of information society, with losing its isolation from main stream society. The old customs of tribes, family and community feelings are decreasing by the impact of media and market. Individualism in place of tribal relationship is given importance. Some of the ideals of tribal life are disfavored after coming in contact with modern life style.

The use of communication technology, the tribes are gaining new found self confidence. These Technologies created a hope that they are part of the globe. Due to penetration and expansion of media technologies the young are learning from the new media content and in turn the old are learning from the young. The tribes are hearing new things with Radio and seeing new things with Television and talking with distant persons with mobile phones. Tribes used to attach themselves mostly to land, forest, folk culture and face to face human relations. But, now, in addition to these, they are excessively attached to mobile phone, radio and DTH TV.

\section{References:}

[1] Uma Joshi, 2001. Understanding Development Communication, Dominant Publishers Distributors, New Delhi. P-104.

[2] Ahuja B.N and Shakti Batra, 1978. Mass Communication (Press, Radio, TV, Films, Advertising and other Media), Verma Brothers, New Delhi. P-42-43.

[3] Abdul Momen Miah and Abdul Halim, 1994. Flow of Agricultural Information, Indian Journal of Extension Education, Vol,xxx, No. 1 to 4 . 


\section{Notes:}

[1] By definition regular listener means to listen to the Radio programmes more than 4 times in a week (or greater than 16 times in the month), the occasional listener means to listen to Radio programmes 2-3 times in a week (or 10-14 times in a month) and casual or rare listener means to listen to Radio programmes at least 1 time in a week (or 4-8 times in a month). 